\title{
Multiphase formation of superimposed ice during a mass-balance year at a maritime high-Arctic glacier
}

\author{
Jemma L. WADHAM, ${ }^{1}$ Anne-Marie NUTTALL ${ }^{2}$ \\ ${ }^{1}$ Bristol Glaciology Centre, School of Geographical Sciences, Bristol University, University Road, Bristol BSo 1SS, England \\ E-mail:j.l.wadham@bris.ac.uk \\ ${ }^{2}$ School of Biological and Earth Sciences, Liverpool John Moores University, Byron Street, Liverpool L3 3AF, England
}

\begin{abstract}
Meteorological and snow-temperature data from midtre Lovénbreen, Spitsbergen, Svalbard, indicate two distinct annual phases of rapid snowpack warming and superimposed-ice formation in 1998/99. Short periods of positive air temperatures in early winter, lasting up to 36 hours and often coinciding with rainfall, caused rapid glacierwide melting. Percolating water froze to form superimposed ice on the lower half of the glacier, and wetted-refrozen snow and ice lenses at higher altitudes. The second period of superimposed-ice formation commenced in May/June 1999 and continued for 5 weeks at low altitudes and throughout the summer at high altitudes. These observations at midtre Lovénbreen are typical of Spitsbergen glaciers and reflect the unique climatology of the region. They contrast with those from glaciers in more continental climatic settings where superimposed-ice formation is confined to a single period during summer. There are significant implications for glacier mass balance, with superimposed ice locally comprising up to $20 \%$ of winter balances and accounting for $\sim 16-25 \%$ of the annual accumulation. Since projected climatic warming is greatest during the winter months in Arctic regions, superimposed ice may become an increasingly important component of the winter, and potentially the net, balance of Spitsbergen glaciers.
\end{abstract}

\section{INTRODUGTION}

Superimposed ice is commonly formed at the base of the snowpack on Arctic glaciers, when percolating water (snowmelt and sometimes rain) freezes onto the cold glacier surface (Baird, 1952). Its formation impinges on a wide range of glaciological processes. Superimposed ice may form a significant component of the mass-balance budget of Arctic glaciers (Schytt, 1949; Baird, 1952; Müller, 1962; Koerner, 1970; Jonsson and Hansson, 1990), accounting for all mass accumulation in some instances (Paterson, 1969; Greuell and Oerlemans, 1989). Its formation may also influence a glacier's thermal regime (Greuell and Oerlemans, 1989; Paterson, 1994), surface energy balance and supraglacial hydrology (Pfeffer and others, 1991). For these reasons, a complete understanding of the formation of superimposed ice and its sensitivity to climate change is important. Research on superimposed-ice formation to date has focused almost entirely on ice masses in Arctic continental climatic settings such as the Canadian Arctic (Ward and Orvig, 1953; Koerner, 1970; Woodward and others, 1997), Alaska (Wakahama and others, 1976; Trabant and Benson, 1986) and Greenland (Braithwaite and others, 1994). Superimposed-ice formation on glaciers with a more maritime polar climatology, such as those in Spitsbergen, is poorly documented by comparison. Knowledge of superimposed-ice formation processes on these ice masses is pertinent given the known sensitivity of maritime glaciers to climate change (Fleming and others, 1997).

Superimposed-ice formation in continental Arctic climatic settings takes place in summer, during the retreat of the snowpack up-glacier (Koerner, 1970). Winter air temperatures well below $0^{\circ} \mathrm{C}$ mean that this is the only period for formation of superimposed ice on these glaciers. In contrast, glaciers in more maritime climatic settings may be subject to more than one annual period of melting. This paper focuses on processes of superimposed-ice formation in Spitsbergen, Svalbard, where mean annual air temperatures are on average $-6^{\circ} \mathrm{C}$ and positive air temperatures occur during winter as well as summer (Hanssen-Bauer and others, 1990).

Glaciers in Spitsbergen have been studied intensively, with the mass balance of two in particular, midtre Lovénbreen and neighbouring austre Brøggerbreen in northwestern Spitsbergen, being used to predict sea-level rise for the Norwegian Arctic (Dowdeswell, 1995; Fleming and others, 1997). However, no detailed studies of superimposed-ice formation in Spitsbergen exist. Jonsson and Hansson (1990) analyzed a core from Storøyjøkulen, an ice cap east of Nordaustlandet, which is entirely composed of superimposed ice. In this instance, neglect of superimposed ice in mass-balance models would lead to overestimation of predicted sea-level rise due to climatic warming. However, it is unlikely that observations, in the far northeastern part of Svalbard, can be transferred directly to the mainland of Spitsbergen, where climatic conditions are heavily influenced by proximity to the North Atlantic Ocean and Gulf Stream (Hanssen-Bauer and others, 1990). Unless superimposed-ice formation processes are well known, the mass balance and mass-balance sensitivity to climate change of these glaciers cannot be fully understood. 


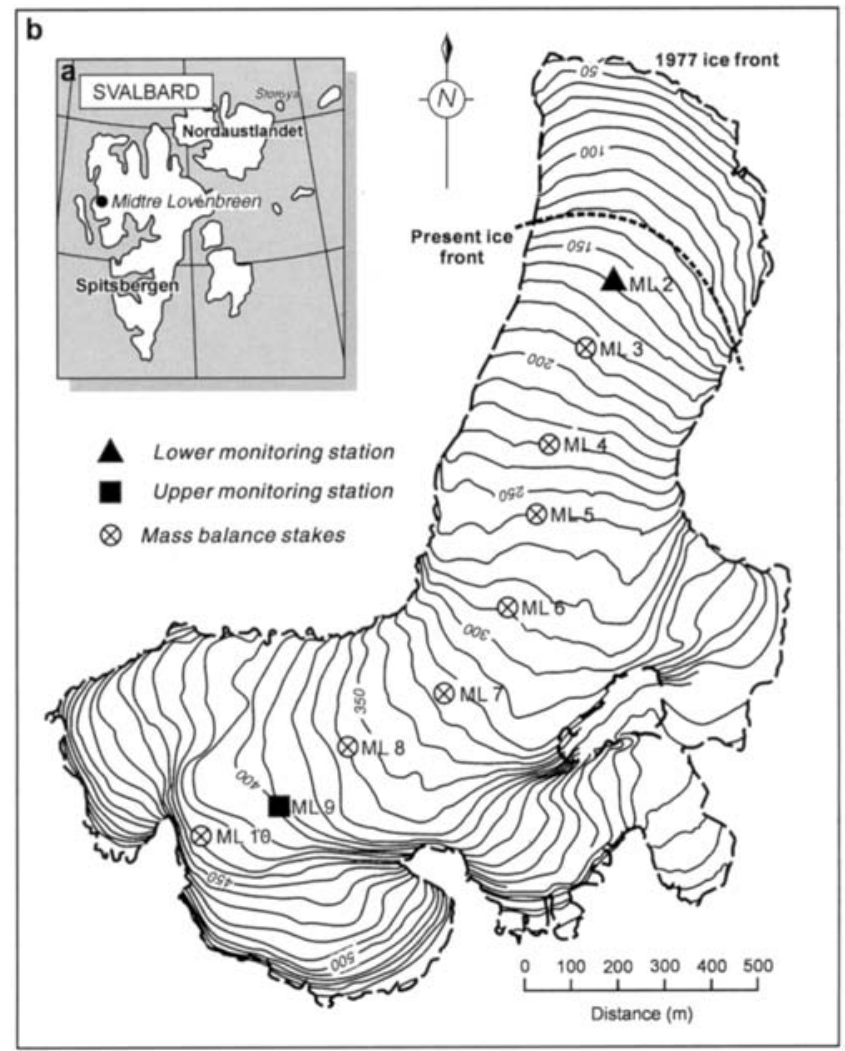

Fig. 1. (a) Map of Svalbard showing the location of midtre Lovénbreen. (b) Map of midtre Lovénbreen (adapted from the 1977 Norsk Polarinstitutt map).

\section{STUDY AREA}

Svalbard is an archipelago, of which Spitsbergen is the largest island (Fig. la). It has a maritime Arctic climate and is $60 \%$ glacierized (Hagen and others, 1991). Long-term massbalance monitoring has been conducted on seven glaciers in Svalbard: Finsterwalderbreen (1950-67, 1994-95), austre Brøggerbreen (1966-present), midtre Lovénbreen (1967present) and Kongsvegen (1987-present) by the Norsk Polarinstitutt (Hagen and others, 1991); Vøringbreen (197491) by Russian workers (Troitskiy, 1989, 1991); and Hansbreen (1990-95) and Bertilbreen (1976-85) by Polish workers (Jania and Hagen, 1996). Of these, only mass-balance records from the first two or three have been used to calculate the contribution of Svalbard glaciers to future sea-level rise (Dowdeswell, 1995; Fleming and others, 1997).

Midtre Lovénbreen ( $78^{\circ} 53^{\prime}$ N; Fig. la) was selected for the research on superimposed ice reported in this paper. The glacier is $6 \mathrm{~km}^{2}$ and is polythermal. The mean annual air temperature in Ny Ålesund, located at sea level $6 \mathrm{~km}$ west of the glacier, is $-6^{\circ} \mathrm{C}$, and the melt season lasts on average from June to early September. The mean winter accumulation at midtre Lovénbreen for 1967-88 was $0.73 \pm 0.18 \mathrm{~m}$ (Hagen and others, 1991). Both midtre Lovénbreen and its neighbour, austre Brøggerbreen, have exhibited negative mass balance during most of the mass-balance monitoring period. This is believed to reflect a general trend of glacier retreat this century since the Little Ice Age maximum (Hagen and others, 1991). Accumulation on the two glaciers comprises both firn and superimposed ice (Hagen and others, 1991). Although the latter has been estimated as $10-30 \%$ of total accumulation (Hagen and others, 1991), the processes and timing of its formation are poorly documented.

\section{METEOROLOGICAL AND SNOW-TEMPERATURE MONITORING}

Air temperature and snow depths were monitored continuously from September 1998 to September 1999 at monitoring stations at Norsk Polarinstitutt mass-balance stakes ML9 and ML2, respectively (Fig. 1b), on the upper and lower glacier. Air temperature was measured with a Campbell Scientific T107 temperature probe at the upper station and a Campbell Scientific HMP45C temperature probe at the lower station. Both were housed in radiation shields. Snow depths were measured with a Campbell Scientific SR50 sonic-ranging sensor mounted at least $0.5 \mathrm{~m}$ above the glacier surface. Recordings of distance to the surface were validated by manual measurements in September 1998, April 1999 and September 1999. Wind speed was also measured at the lower station using a Campbell Scientific R M Young wind monitor, mounted $>1 \mathrm{~m}$ above the snow surface. Instantaneous hourly measurements from the sensors were recorded by a Campbell Scientific CR10X data logger at each monitoring station.

Instantaneous snowpack temperatures were monitored every 1 and 2 hours at the upper and lower stations, respectively, using strings of up to 10 thermistors connected to a Campbell Scientific CR10X data logger. Fenwal Uni-curve type negative temperature coefficient thermistors, with a resistance of $2252 \Omega$ at $25^{\circ} \mathrm{C}$, were positioned vertically at 5$20 \mathrm{~cm}$ intervals, but closer near the ice/snow interface. Thermistor strings were located 1-2 m from sensors monitoring the meteorological variables. Each thermistor was connected to a Campbell Scientific CR10X data logger in a three-wire half-bridge configuration using a precision fixed resistor of $255 \mathrm{k} \Omega$. Thermistors were individually calibrated in the laboratory at five or six different temperatures in the range $-23^{\circ}$ to $+10^{\circ} \mathrm{C}$. Typical errors quoted for such a thermistor set-up and configuration are of the order $\pm 0.03^{\circ} \mathrm{C}$ (Ødegård and others, 1997) and include possible drift over time, calibration slope errors and errors introduced by the data logger.

\section{SNOW STRATIGRAPHY AND SUPERIMPOSED-ICE MEASUREMENTS}

Detailed observations of snow stratigraphy and superimposed-ice type, distribution and thickness were made at the end of the 1998/99 accumulation and ablation seasons.

Spring sampling was conducted at the end of the 1998/99 accumulation period, from 30 April to 11 May 1999. Snow pits, $2 \mathrm{~m}^{2}$ in area at the base, were excavated at Norsk Polarinstitutt mass-balance stakes ML2, ML5, ML7 and ML9 (Fig. 1b). Snow depths and the stratigraphy of the snowpack were recorded. Samples from each snow pit were collected with a plastic cylinder at regular depths and used to calculate snow density. Density measurements from ML7 are not used since air temperatures during sampling were $>0{ }^{\circ} \mathrm{C}$ and the upper part of the snow profile was wet.

The presence, thickness and character of superimposed ice at ML2, ML5, ML7 and ML9 were determined from detailed excavations of surface ice at the base of snow pits and from shallow ice cores. Sediment layers and plastic mesh, laid on the glacier surface at the end of summer 1998, served as marker horizons for the previous year's summer surface. Shallow ice cores, 0.5-2 m long, were recovered with a Polar Ice Coring Office (PICO) manual ice corer and then described in detail. They were sectioned and the dimensions and weight of each section measured to obtain 


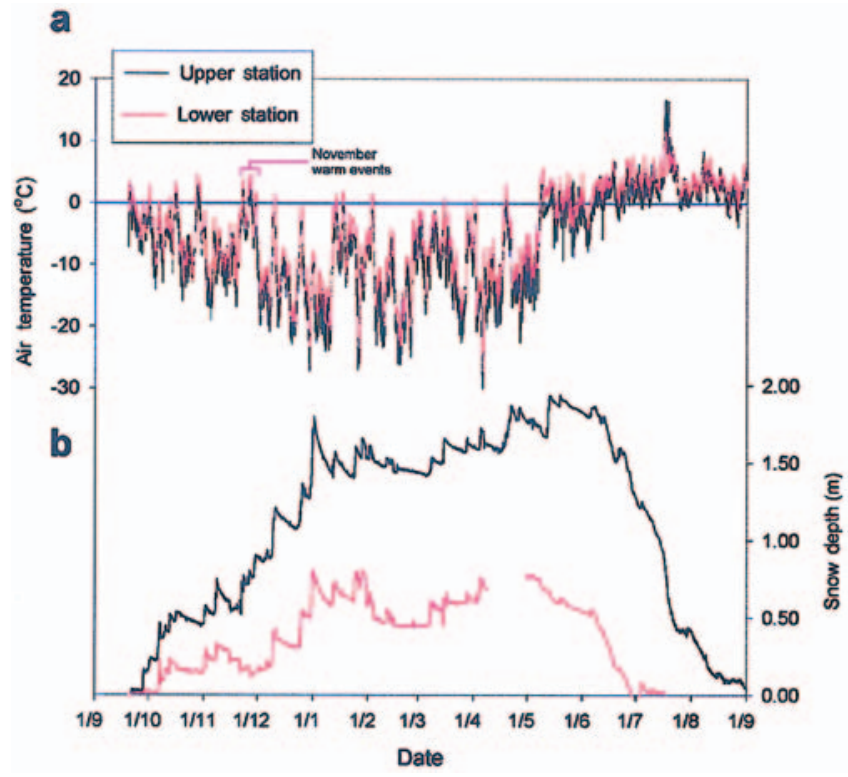

Fig. 2. Temporal variation in hourly air temperature and snow depth at the lower and upper monitoring stations, September 1998-September 1999.

ice density. Where the ice facies lacked strong cohesion, regularly shaped blocks were carved directly from the snow-pit base. Their dimensions and weights were used to determine density. Spring ice-core and snow-pit ice samples were stored at $-20^{\circ} \mathrm{C}$ in a cold room prior to analysis.

Summer sampling was carried out at the end of the ablation season, from 25 August to 4 September 1999. The ice surface at ML2, ML5, ML7 and ML9 was described in detail and any superimposed ice noted. The thickness of the annual layer of superimposed ice in the accumulation zone (above ML8) could be determined visually from the banding of near-surface ice and sediment horizons. Superimposed-ice facies in the accumulation zone were observed in detail and logged.

\section{RESULTS}

\section{Annual meteorological conditions}

The temporal variation in air temperature and snow depth, from September 1998 to September 1999 at the lower and upper glacier monitoring stations, are displayed in Figure $2 \mathrm{a}$ and $\mathrm{b}$. Most snow accumulation in this period took place in early winter, from October toJanuary. Air temperatures fluctuated markedly from September to May, with positive values on more than 10 occasions at both stations. Hereafter these are termed "winter warm events". From May to July, air temperatures increased rapidly to positive values after the winter cold period. Both the winter warm periods and this early summer period are times of potential superimposed-ice formation.

\section{Winter meteorology and snowpack conditions}

Figure 3 a displays the temporal variations in air temperature and snow depth recorded at the upper and lower monitoring stations during three winter warm events on 22-23, 25-27 and 29 November. These were the only winter warm events in 1998/99 to warm the snowpack to $0^{\circ} \mathrm{C}$ (Fig. 2) and are termed the first, second and third November warm events, respectively. They lasted 21, 58 and 15 hours, respectively, at the lower

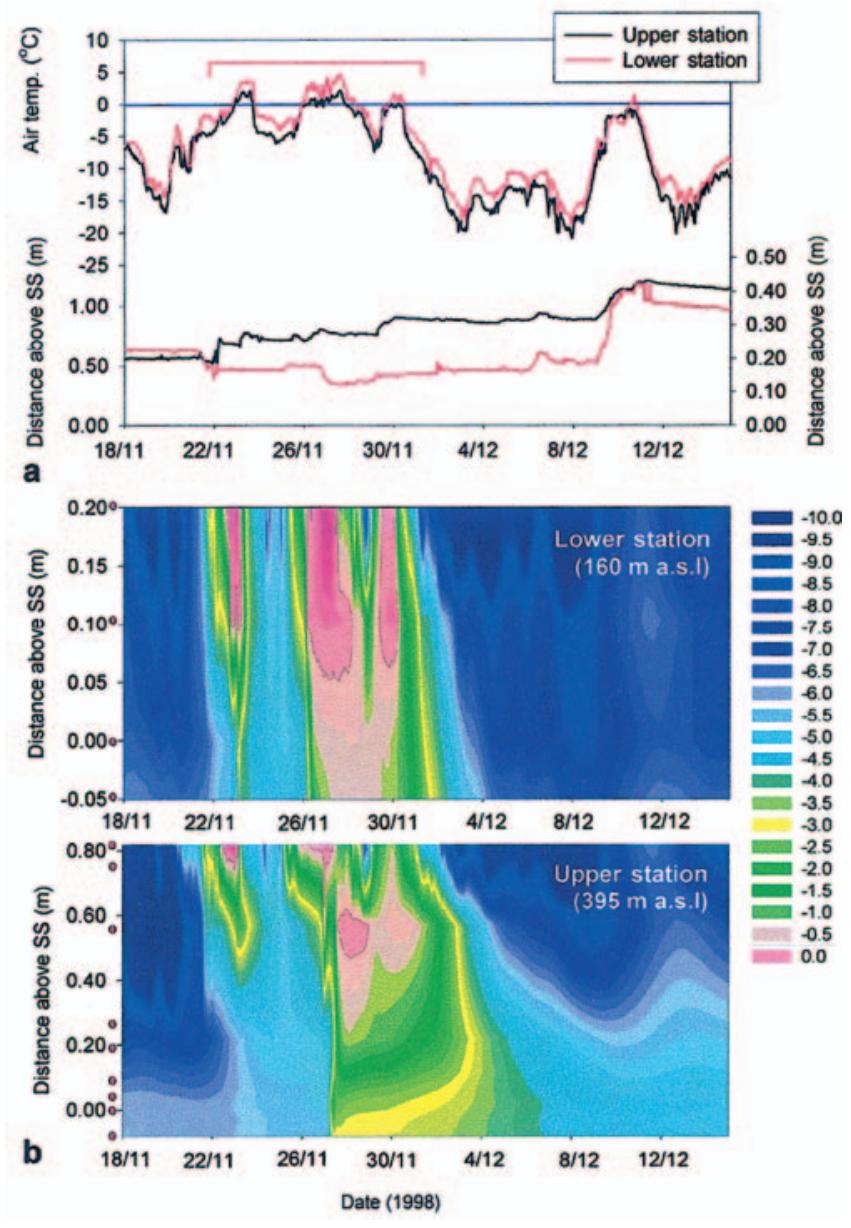

Fig. 3. Temporal variation in (a) hourly air temperature and snow depth and $(b)$ snowpack temperatures at the lower and upper stations, 18 November-15 December 1998 (thermistor locations are denoted on the y axis with "•" and the contour). SS is summer surface.

station and 19, 38 and 1 hour, respectively, at the upper station. Snow depths at the upper station increased over the course of the three events, with intermittent periods of decrease. Snow depths at the lower station remained relatively constant until the second warm event, when they decreased by $\sim 0.1 \mathrm{~m}$. There was heavy rainfall during this event $(33 \mathrm{~mm}$ on 27 November) as indicated by data from Ny Ålesund recorded by the Norsk Meteorologisk Institutt. Rainfall during the other warm events was minimal ( $<1 \mathrm{~mm})$.

Snowpack temperatures during these events are displayed in Figure 3b, which depicts temperatures as colours in a time-depth domain. Snow temperatures are interpolated linearly between thermistors. Given the error range of the thermistors, some of the snow shaded to indicate temperatures of $0^{\circ}$ to $-0.5^{\circ} \mathrm{C}$ was probably wet. At the upper station, only the top $0.3 \mathrm{~m}$ of the snowpack reached $0^{\circ} \mathrm{C}$. At the lower station, most of the snow profile warmed to $0^{\circ} \mathrm{C}$.

Ice lenses and wetted-refrozen snow were common in the lower $0.6 \mathrm{~m}$ of the spring-snow stratigraphic profiles (Fig. 4). Much of the wetted-refrozen snow was of high density $\left(600 \mathrm{~kg} \mathrm{~m}^{-3}\right)$ and impenetrable by snow probe. Superimposed ice was present at ML2 and ML5 and comprised a layer of dense, clear blue ice $\left(900 \mathrm{~kg} \mathrm{~m}^{-3}\right.$ ) (Wadham and Nuttall, unpublished). According to the snowpack thermistor records, the only time for these features to have formed was during the November warm events.

Figure 4 shows that superimposed-ice thickness decreased with increasing altitude. Summation of the water equivalents 
Clear blue ice

Snow ice

Oog Fresh or recent compacted snow

口 Faceted crystals

$\wedge \quad$ Cup shaped crystals

$\wedge$ Depth hoare

œ Wetted refrozen snow

- Ice lense

ML 2

(160 $\mathrm{m}$ a.s.I.)

$100-0000000$

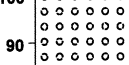

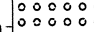

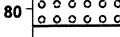

$70-\square$

60

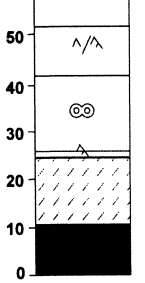

ML 5
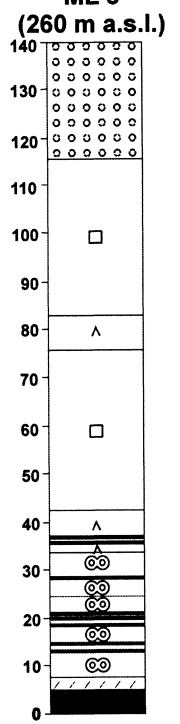

ML 9

(395 $\mathrm{m}$ a.s.l.)

0000000

$170-\div 00000$

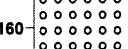

ML 7

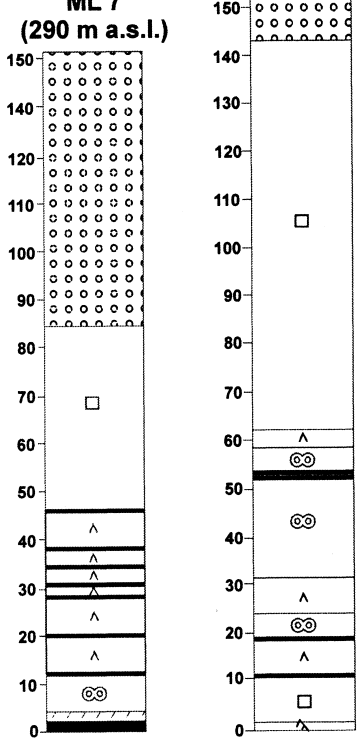

Fig. 4. Spring stratigraphic profiles of the snowpack at ML2, ML5, ML7 and ML9 showing ice lenses, wetted-refrozen snow, depth hoar and superimposed ice. SS is summer surface.
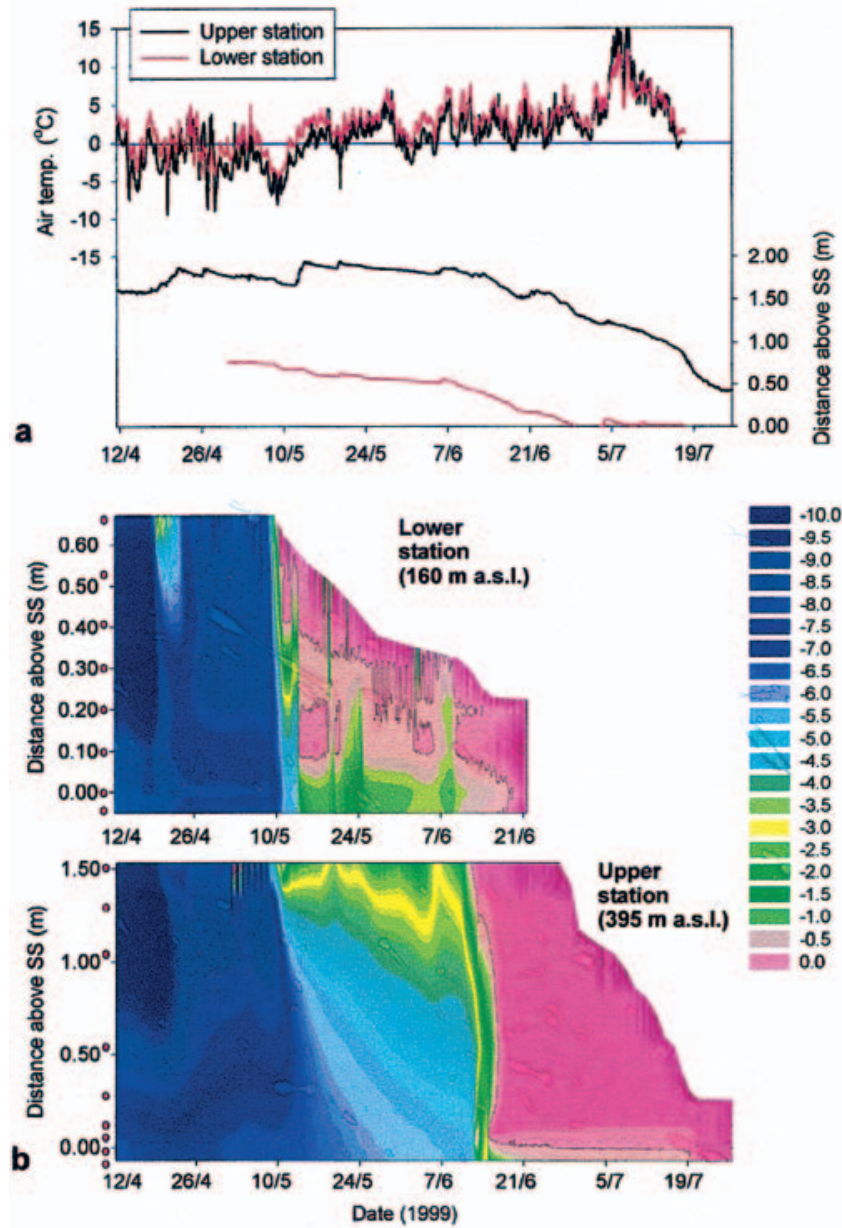

.10 .0

Fig. 5. Temporal variations in (a) hourly air temperature and snow depth and (b) snowpack temperatures at the lower and upper stations, 4 April-25 July 1999 (thermistor locations are denoted on the $y$ axis with “•”). SS is summer surface.

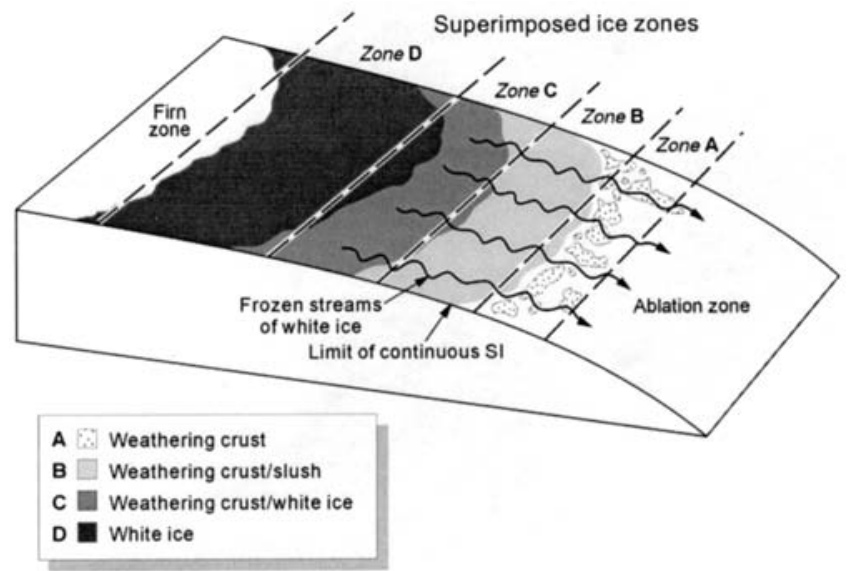

Fig. 6. Conceptual model showing zonation of the accumulation area at midtre Lovénbreen at the end of the 1999 ablation season.

(w.e.) of superimposed ice, ice layers and the higher-density wetted-refrozen snow, present in the snowpack, gives totals of 0.18, 0.17 and $0.11 \mathrm{~m}$ w.e. for ML2, ML5 and ML9, respectively. These totals accounted for up to $40 \%$ of winter accumulation at low-altitude sites such as ML2, and contributed about $6 \%$ to the glacier-wide winter balance in 1998/99. Superimposed ice alone accounted for $\sim 20 \%$ of winter accumulation at ML2.

\section{Summer meteorology and snowpack conditions}

Air temperatures and snow depths recorded at the lower and upper monitoring stations from 11 April to 25 July 1999 are presented in Figure 5a. Sustained positive air temperatures were first recorded on 11 and 13 May at the lower and upper stations, respectively. By 28 June the snowpack at the lower station had been removed. Since the upper station was in the accumulation zone, complete snowpack ablation did not take place. Figure $6 \mathrm{~b}$ shows temporal variations in snow temperature at the upper and lower stations during the same period. From early May to late June, the snowpack at both stations warmed to $0^{\circ} \mathrm{C}$.

Superimposed ice was preserved at the end of 1998/99 150-400 m down-glacier from the upper station and $\sim 50 \mathrm{~m}$ down-glacier from ML10. It increased in thickness with distance up-glacier, attaining a maximum thickness of $0.15 \mathrm{~m}$ close to ML10. It accounted for $\sim 16 \%$ of the water equivalent of the annual accumulation in this balance year. Fieldwork, not reported here, indicated a contribution of $\sim 25 \%$ in 1999/2000. Four zones of superimposed-ice accumulation were identifiable (Fig. 6). The streams of white ice, observed in zones $\mathrm{A}-\mathrm{C}$, were sinuous features up to $50 \mathrm{~m}$ long, raised $5-15 \mathrm{~cm}$ above the local superimposed-ice surface. The underlying superimposed ice was $2-10 \mathrm{~cm}$ thick.

\section{DISGUSSION}

Prerequisites for superimposed-ice formation on Arctic glaciers are snowpack melting and/or rainfall, the delivery of this water to the snowpack base, and a cold glacier surface. Data presented here indicate that these conditions may exist periodically throughout the year on Svalbard, in winter, summer and autumn.

\section{Winter superimposed-ice formation}

The winter warm events identified in the 1998/99 meteorological record are typical of the maritime Arctic climate of Spitsbergen and reflect the position of the island in the border 
zone between cold Arctic air to the north and mild maritime air to the south (Hanssen-Bauer and others, 1990). Periodically, warm southerly air penetrates Spitsbergen, producing periods of positive air temperatures throughout the winter (Hannssen-Bauer and others, 1990).

The snow-temperature time series and snow-pit stratigraphy data provide clear evidence for large-scale snowpack melting and superimposed-ice formation on the lower part of midtre Lovénbreen ( $<300 \mathrm{~m}$ a.s.l.) during the November warm events (Figs 3 and 4). The $2-11 \mathrm{~cm}$ layer of dense, clear, blue superimposed ice, observed at the base of spring snow pits ML2-ML7, is inferred to form by the relatively slow freezing of a water-saturated slush layer at the snowpack base. The overlying layer of wetted-refrozen snow reflects the cyclic melting and/or wetting by rain and freezing of an unsaturated snow layer as air temperature fluctuated during these warm events. There is evidence for rapid and spatially variable infiltration into the cold snowpack during the warm events. For example, localized warming to $0^{\circ} \mathrm{C}$ at $0.4-0.6 \mathrm{~m}$ at the upper station during the second November warm event indicates piping of percolating water into the adjacent snowpack, followed by lateral flow to the thermistor string. Similar observations of premature warming at depth have been made elsewhere and attributed to the same phenomenon (Woo and Heron, 1981; Conway and Benedict, 1994; Pfeffer and Humphrey, 1996). The presence of depth hoar and faceted crystals throughout most snow profiles indicates rapid kinetic crystal growth due to high temperature and vapour-pressure gradients within the snowpack. This is consistent with the extreme temperature fluctuations associated with winter warm events during winter 1998/99.

The decrease in superimposed-ice thickness and increase in the abundance of ice layers and wetted-refrozen snow with increasing altitude (Fig. 4) reflect two processes. The first is a decrease in melting with increased altitude. For example, there was a mean air-temperature difference of $2^{\circ} \mathrm{C}$ between the lower and upper stations during the November warm events. Second, an increase in snow depth with distance up-glacier hindered water percolation to the snowpack base, promoting the formation of ice layers and wetted-refrozen snow at higher altitudes. Of the winter warm events, the second November warm event caused the most extensive snowpack melting, with snow-depth decreases being recorded at both monitoring stations. This is attributed to its longer duration and the occurrence of significant rainfall on 27 November that accentuated snowpack warming.

These findings imply that the extent of snowpack melting during winter warm events is sensitive to temperature conditions during the event, the event duration and its coincidence with rain events. The depth to which snowmelt and rain percolate within the snow pack prior to freezing depends on snow depth and the snow/summer-surface temperature conditions. Although only 1 year's data are reported here, observations by the authors at midtre Lovénbreen in 1999/2000, 2000/01 and 2001/02 and at other Svalbard glaciers (Wadham, 1997) indicate that winter snowpack melting and superimposedice formation are a common occurrence.

\section{Summer superimposed-ice formation}

In Arctic regions, such as northern Canada and Greenland, where winter temperatures are continually below $0^{\circ} \mathrm{C}$, virtually all superimposed ice forms during summer. In this study, we assume that superimposed-ice formation ceased once the glacier surface layer was isothermal at $0^{\circ} \mathrm{C}$. This took place on 20 June at the lower station and on 19 July at the upper station, giving a formation time of about 5 weeks at both sites (Fig. 5). There was some renewed superimposed-ice formation at the upper station in autumn as atmospheric cooling led to refreezing of slush pools in the accumulation area.

Refreezing of meltwater at the lower station during summer was facilitated by both contact with the cold ice surface and atmospheric cooling during prolonged ( $>1$ day) periods of sub-zero air temperature in late May and early June (Fig. 5). A thicker snowpack at the upper station prevented atmospheric cooling of the entire snowpack, and meltwater refreezing was induced mainly by contact with the cold ice substratum. Progressive warming of the snow/ice interface to $0^{\circ} \mathrm{C}$, during the superimposed-ice formation period, is evident from the snow-temperature record (Fig. 5b), indicating the release of latent heat to the underlying ice surface.

It is clear from the snow-temperature record from both stations that superimposed ice and ice layers formed in winter 1998/99 influenced patterns of snowpack melting the following summer. The former summer surface $(0.0 \mathrm{~m})$ at the lower station remained $<0^{\circ} \mathrm{C}$ for much of the monitoring period, being isolated from water infiltration by an overlying layer of winter-formed superimposed ice (Fig. 5b). The premature warming to $0^{\circ} \mathrm{C}$ at $0.1 \mathrm{~m}$ about 17 May at this site, relative to the overlying snow profile, also indicates rapid delivery of meltwater to the snowpack base by piping through subfreezing snow near the thermistor string. The subsequent lateral movement of this piped meltwater must have taken place either within or at the base of the winter-formed, wetted-refrozen snow. The delayed warming of snow at $0.15-1.0 \mathrm{~m}$ depth at the upper station in mid-June probably also reflects the impedance of meltwater infiltration by winter-formed ice lenses in the lower part of the snowpack (Fig. 5b). These inferences about spatial patterns of melting and refreezing align closely with those made from the winter data series and highlight the role of snow stratigraphy and preferential meltwater flow in controlling spatial and temporal patterns of meltwater delivery and superimposed-ice formation. Such findings have implications for the parameterization of superimposed-ice formation in numerical models, which usually assume no superimposed-ice formation until the snow is isothermal at $0^{\circ} \mathrm{C}$.

The area in which there was net superimposed-ice accumulation at the end of the ablation season showed clear zonation (Fig. 6), reflecting spatially variable superimposed-ice accretion and its subsequent ablation once the snowpack had been completely removed. Zone D, just below the snowline, contains the most recently formed superimposed ice. This ice was white in appearance ("white ice”), being low in density and high in air-bubble content, suggesting a formation time in the early melt period, when the glacier surface was cold and freezing would have been rapid. Similar observations of superimposed-ice facies have been made in early summer on the lower glacier (personal communication from A. J. Hodson, 2000) and at glaciers in Arctic Canada and Greenland (Schytt, 1955; Shumskii, 1964). The smooth surface of the white ice indicates that some subaerial melting or sublimation, and refreezing, took place subsequent to snowpack removal. The superimposedice weathering crust present in zones $\mathrm{A}-\mathrm{C}$ was formed by the ablation and melt-freeze metamorphism of superimposed ice. Only in zone $\mathrm{G}$ was this crust underlain by any white ice similar to that found in zone D. The lack of a 
cohesive underlying layer in zone B indicates that all superimposed ice formed in the year of study had been weathered to a crust. This crust, acting as a collection point for meltwater at the end of the ablation season, refroze slowly through September and October to form superimposed ice.

The frozen streams in zones $\mathrm{A}-\mathrm{C}$ are believed to have formed as meltwater and slush drained from the superimposed-ice/firn-zone edge in the mid- to late melt season, freezing when air temperatures periodically fell below $0^{\circ} \mathrm{C}$ (Fig. 2). This is consistent with an increase in glacier surface gradients between zones $\mathrm{C}$ and A. Similar observations have been made on glaciers in Arctic Canada (personal communication from R. M. Koerner, 2001). Such drainage of meltwater complicates numerical prediction of superimposed-ice thickness, which usually assumes that refreezing takes place on a flat surface and runoff is zero (Wakahama and others, 1976; Woodward and others, 1997).

\section{Implications for glacier mass balance}

It is likely that multiple superimposed-ice-formation periods are not unique to Spitsbergen, but operate to varying degrees at glaciers in other polar maritime climatic settings where there is significant warming above freezing and rainfall during winter (e.g. parts of the Antarctic Peninsula; the subAntarctic Islands (Gardiner, 2000); southern Greenland; and southern Arctic Canada (personal communication from R. M. Koerner, 2001)).

The layer of superimposed ice and dense wetted-refrozen snow found at the base of the winter snowpack may be $\sim 6 \%$ of total winter accumulation and up to $40 \%$ of winter accumulation at low altitudes. This component is often neglected in mass-balance records. Since this layer of winter-formed superimposed ice and dense wetted-refrozen snow is impenetrable, snow-sounding measurements only measure the thickness of snow above these layers, and hence do not include the superimposed-ice component (Østrem and Brugman, 1991). If mass balance is measured twice annually, in spring and autumn, failure to measure superimposed ice and wetted-refrozen snow leads to underestimation of winter balances and overestimation of summer ablation. However, since these errors broadly compensate for each other over an annual cycle, the net balance does not alter significantly. Where annual mass balance is only measured once in spring, there would be overestimation of one year's accumulation and underestimation of the following year's annual and winter balances. These errors would not compensate for each other over an annual cycle. Where balances are only measured in autumn, winter formation of superimposed ice does not affect the balance record.

This study indicates that a significant proportion (16$25 \%$ ) of the annual accumulation on Spitsbergen glaciers may be comprised of superimposed ice. Some accumulation is also likely to derive from meltwater refreezing in firn (internal accumulation) (Trabant and Mayo, 1985). A full evaluation of the importance of this latter process, however, is beyond the scope of this paper.

Any studies of the mass-balance response to global warming in Spitsbergen need to take account of the specific impact of a changing climatic regime on superimposed-ice formation and internal accumulation, in addition to firn accumulation. An initial response of glaciers to warming climate is believed to be an increase in the refreezing of meltwater both at the glacier surface, to form superimposed ice, and within the firn during percolation (Pfeffer and others, 1991). Detailed work on these processes is currently lacking. A number of studies have demonstrated that the amount of superimposed ice formed is a function of the temperature of the underlying ice and the rate of delivery to the snow/ice interface (Wakahama and others, 1976). Hence, a low ice temperature and rapid meltwater delivery would favour maximum superimposed-ice formation. Only one study to date has investigated the possible effect of increased air temperatures on superimposed-ice formation in summer, predicting a decrease in thickness at a point with increased air and surface ice temperatures (Woodward, 1996).

No study has explored the consequences of climatic warming for superimposed-ice formation during winter. Since winter warming is projected to be more pronounced than summer warming in Arctic regions (McGinnis and Crane, 1994; Houghton and others, 2001), this is a pertinent issue on Spitsbergen and in other maritime areas where significant variability in winter air temperatures exists. Although the mean monthly temperatures may remain significantly below $0^{\circ} \mathrm{C}$, the frequency, duration and intensity of winter warm periods would be expected to increase in these areas as a result of global warming. Provided sufficient atmospheric cooling of the snowpack occurs in between winter warm periods, superimposed-ice formation during winter would also be expected to become more significant. This may include an increased thickness of superimposed ice at lower altitudes, and the initiation of winter superimposed-ice formation at higher altitudes, where freezing of rain or meltwater currently only produces ice lenses. If winter superimposed-ice formation extended into the superimposed-ice zone of the accumulation area, there would be the potential to influence the net mass balance in addition to winter balances. It is also feasible that increased winter air temperatures, in high-Arctic regions that do not currently undergo winter melting but where significant winter climatic variability exists, may lead to the formation of ice lenses and superimposed ice during this time period. These inferences contrast with the common assumption that winter warming would have no impact on glacier mass balance (Braithwaite and Olesen, 1991).

\section{GONGLUSIONS}

Meteorological and snowpack-temperature data, together with field studies of snowpack stratigraphy and superimposed-ice thicknesses and characteristics, indicate two major periods of superimposed-ice formation at midtre Lovénbreen, early winter and summer. Although air temperatures on Spitsbergen glaciers often exceed $0^{\circ} \mathrm{C}$ during winter, superimposed-ice formation only results from a particular combination of snowpack and meteorological conditions. The probability of superimposed ice forming increases when warm periods last several days, are accompanied by rainfall and occur in early winter when the snowpack is thin. Air temperature and snow depth determine how much and where freezing of percolating water takes place, by controlling melt rate and the depth of percolation, respectively. Typically, superimposed ice is formed on the lower part of the glacier, with ice lenses forming at high altitudes where melt rates are reduced and the thicker snowpack impedes water percolation to the glacier's summer surface. During summer, a second period of superimposed-ice 
formation commences with meltwater refreezing on top of the winter-formed superimposed ice. Snowpack-wetting patterns are strongly influenced by the presence of winterformed superimposed ice and ice lenses. The main summer formation period is about 5 weeks, although some superimposed-ice formation may continue into autumn in the accumulation area. Superimposed ice and high-density wettedrefrozen snow accounted for $6 \%$ of the winter-balance record in 1998/99, and superimposed ice equalled $\sim 16$ $25 \%$ of the annual accumulation at midtre Lovénbreen in 1998/99 and 1999/2000. These findings have implications for mass balance and its measurement on Spitsbergen glaciers. They are also relevant for climate-warming scenarios for polar maritime glaciers elsewhere and for glaciers in more continental polar regions.

\section{ACKNOWLEDGEMENTS}

This project was funded by the European Commission Training and Mobility of Researchers Programme (NP98-8 and NP99/1-2), the U.K. Natural Environment Research Council ARCICE thematic programme (GST/02/2192), the Nuffield Foundation (SCI/180/97/222), the Royal Geographical Society, the Linnean Society of London and the Scott Polar Research Institute.

We are very grateful to E. Isaksson and J. Kohler of the Norsk Polarinstitutt, and J. O. Hagen of the University of Oslo, for their support and collaboration. The automatic weather station was loaned to the project by A. J. Hodson of the University of Sheffield, and rainfall data for Ny Ålesund were contributed by the Norsk Meteorologisk Institutt. We would also like to thank J. Mills and C. Norris for conducting the chemical analysis of ice samples, J. Tooby and D. Ellis for their help with figure preparation and all those who assisted in the field. We are grateful for the comments of R. M. Koerner, W. D. Harrison, R. March and an anonymous reviewer, which resulted in significant improvements to an earlier version of the manuscript.

\section{REFERENCES}

Baird, P. D. 1952. The glaciological studies of the Baffin Island Expedition, 1950. Part I: Method of nourishment of the Barnes Ice Cap. F. Glaciol., 2(11), 2-9, 17-19.

Braithwaite, R. J. and O. B. Olesen. 1990. A simple energy-balance model to calculate ice ablation at the margin of the Greenland ice sheet. F. Glaciol., 36(123), 222-228.

Braithwaite, R. J., M. Laternser and W.T. Pfeffer. 1994. Variations of nearsurface firn density in the lower accumulation area of the Greenland ice sheet, Pâkitsoq, West Greenland. F. Glaciol., 40(136), 477-485.

Conway, H. and R. Benedict. 1994. Infiltration of water into snow. Water Res. Res., $30(3), 641-649$.

Dowdeswell, J. A. 1995. Glaciers in the High Arctic and recent environmental change. Philos. Trans. R. Soc. London, Ser. A, 352(1699), 321-334.

Fleming, K. M., J. A. Dowdeswell and J. Oerlemans. 1997. Modelling the mass balance of northwest Spitsbergen glaciers and responses to climate change. Ann. Glaciol., 24, 203-210.

Gardiner, M. J. 2000. Snowmelt modelling in the Paternoster Valley, Signy Island, Antarctica. (Ph.D. thesis, University of Bristol.)

Greuell, W. and J. Oerlemans. 1989. The evolution of the englacial temperature distribution in the superimposed ice zone of a polar ice cap during a summer season. In Oerlemans, J., ed. Glacier fluctuations and climatic change. Dordrecht, etc., Kluwer Academic Publishers, 289-303.

Hagen, J. O., B. Lefauconnier and O. Liestøl. 1991. Glacier mass balance in Svalbard since 1912. International Association of Hydrological Sciences Publication 208 (Symposium at St. Petersburg 1990 - Glaciers-Ocean-Atmosphere
Interactions), 313-328.

Hanssen-Bauer, I., M. K. Solås and E. L. Steffensen. 1990. The climate of Spitsbergen. Oslo, Norsk Meteorologisk Institutt. (Rapport 39/90.)

Houghton, J.T. and 7 others, eds. 2001. Climate change 2001: the scientific basis. Cambridge, etc., Cambridge University Press. Intergovernmental Panel on Climate Change. (Contribution of Working Group I to the Third Assessment Report.)

Jania, J. and J. O. Hagen. 1996. Mass balance of Arctic glaciers. Sosnowiec/Oslo, International Arctic Science Committee. Working Group on Arctic Glaciology. (IASC Report 5.)

Jonsson, S. and M. Hansson. 1990. Identification of annual layers in superimposed ice from Storøyjøkulen in northeastern Svalbard. Geogr. Ann., 72A (1), $41-54$.

Koerner, R. M. 1970. Some observations on superimposition of ice on the Devon Island ice cap, N.W.T. Canada. Geogr. Ann., 52A(1), 57-67.

McGinnis, D. L. and R. G. Crane. 1994. A multivariate analysis of Arctic climate in GCMs. f. Climate, 7(8), 1240-1250.

Müller, F. 1962. Zonation in the accumulation area of the glaciers of Axel Heiberg Island, N.W.T., Canada. F. Glaciol., 4(33), 302-311.

Ødegård, R. S., J. O. Hagen and S.-E. Hamran. 1997. Comparison of radioecho sounding (30-1000 MHz) and high-resolution borehole-temperature measurements at Finsterwalderbreen, southern Spitsbergen, Svalbard. Ann. Glaciol., 24, 262-267.

Østrem, G. and M. Brugman. 1991. Glacier mass-balance measurements. A manual for field and office work. Saskatoon, Sask., Environment Canada. National Hydrology Research Institute. (NHRI Science Report 4.)

Paterson, W. S. B. 1969. The Meighen Ice Cap, Arctic Canada: accumulation, ablation and flow. 7. Glaciol., 8(54), 341-352.

Paterson, W. S. B. 1994. The physics of glaciers. Third edition. Oxford, etc., Elsevier.

Pfeffer, W. T. and N. F. Humphrey. 1996. Determination of timing and location of water movement and ice-layer formation by temperature measurements in sub-freezing snow. F. Glaciol., 42(141), 292-304.

Pfeffer, W. T., M. F. Meier and T. H. Illangasekare. 1991. Retention of Greenland runoff by refreezing: implications for projected future sea level change. 7. Geophys. Res., 96 (C12), 22,117-22,124.

Schytt, V. 1949. Re-freezing of the melt-water on the surface of glacier ice. Geogr. Ann., 31 (1-2), 222-227.

Schytt, V. 1955. Glaciological investigations in the Thule ramp area. SIPRE Rep. 28.

Shumskii, P. A. 1964. Principles of structural glaciology. New York, Dover Publications.

Trabant, D. C. and C. S. Benson. 1986. Vliyaniye vnutrennego pitaniya i formirovaniya nalozhennogo l'da na balans massy lednika Makkol na Alyaske / Influence of internal accumulation and superimposed ice formation on mass balance of McCall Glacier in Alaska. Mater. Glyatsiol. Issled. 58, 40-49 (Russian); 157-165 (English).

Trabant, D. C. and L. R. Mayo. 1985. Estimation and effects of internal accumulation on five glaciers in Alaska. Ann. Glaciol., 6, 113-117.

Troitskiy, L. S. 1989. Balans massy lednikov Shpitsbergena v 1985/86, 1986/87 i 1987/88 balansovykh godakh [Mass balance of Spitsbergen glaciers in the 1985/86, 1986/87 and 1987/88 balance years]. Mater. Glyatsiol. Issled.67, 194-197.

Troitskiy, L. S. 1991. Balans massy lednikov Shpitsbergena v 1988/89 i 1989/ 90 balansovykh godakh [The mass balance of glaciers in Spitsbergen in 1988/89 and 1989/90 balance years]. Mater. Glyatsiol. Issled. 72, 167-170.

Wadham, J. L. 1997. The hydrochemistry of a High Arctic polythermalbased glacier, Finsterwalderbreen, Svalbard. (Ph.D. thesis, University of Bristol.)

Wadham, J. L. and A.-M. Nuttall. Unpublished. Impact of superimposed ice formation on the mass balance of north-west Spitsbergen glaciers. European Commission Training and Mobility of Researchers Programme. (Final Report.)

Wakahama, G., D. Kuroiwa, T. Hasemi and C. S. Benson. 1976. Field observations and experimental and theoretical studies on the superimposed ice of McCall Glacier, Alaska. F. Glaciol., 16(74), 135-149.

Ward, W. H. and S. Orvig. 1953. The glaciological studies of the Baffin Island Expedition, 1950. Part IV: The heat exchange at the surface of the Barnes Ice Cap during the ablation period. F. Glaciol., 2(13), 158-168.

Woo, M.-K. and R. Heron. 1981. Occurrence of ice layers at the base of High Arctic snowpacks. Arct. Alp. Res., 13(2), 225-230.

Woodward, J. 1996. The influence of superimposed ice formation on the sensitivity of glacier mass balance to climate change. (M.Sc. thesis, University of Alberta, Edmonton, Alta.)

Woodward, J., M. Sharp and A. Arendt. 1997. The influence of superimposed-ice formation on the sensitivity of glacier mass balance to climate change. Ann. Glaciol., 24, 186-190. 